\title{
Investigation of Indoor Thermal Environment for Rural Passive Solar House in Zhongwei of Ningxia Area
}

\author{
Guochen Sang ${ }^{\mathrm{a}}$, Deyong Chen ${ }^{\mathrm{b}}$, Yan Han ${ }^{\mathrm{c}}$, Yiyun Zhu ${ }^{\mathrm{d}}$, Qin Zhao ${ }^{\mathrm{e}}$
}

School of Civil Engineering and Architecture, Xi'an University of Technology, Xi'an 710048, China

aemail: sangguochen@xaut.edu.cn, bemail: 735775330@qq.com , cemail: 1054119701@qq.com,

demail: zyyun@xaut.edu.cn, eemail:zhaoqin6688@xaut.edu.cn

Keywords: Zhongwei region; passive solar house; operating temperature; solar radiation intensity Abstract: In order to probe into and solve the problems of rural residential heating by using solar energy in winter, the indoor and outdoor thermal environmental parameters of a passive solar heating house are tested and indoor thermal environment is analyzed and evaluated using the operating temperature in this paper. Results show that the local rich solar energy resources are suitable for the development of passive solar houses and through the rural architecture with the sunlight directly and the transition temperature region reasonable setting can effectively improve the thermal environment quality in the main rooms of existing rural house. But the quality of the indoor thermal environment in winter of existing rural buildings is not ideal. With low indoor temperature and large temperature fluctuations, so that it is necessary to strengthen the heat collection and heat storage design of architectures.

\section{Introduction}

In northwest China where there are the fragile ecological environment, the low urbanization level and harsh climate condition, the contradictions between ecological environment protection and the improvement of indoor thermal environment are becoming more and more serious in rural areas. Zhongwei region in Ningxia is located in the hinterland of northwest and it is located in the Ningxia autonomous region, Gansu province and Inner Mongolia autonomous region convergence zone, where climatic features and residential characteristics are of northwest rural representativeness. Zhongwei region is one of the high energy regions of the solar radiation in China. In this region, annual amount of solar radiation that reaches $5781 \mathrm{MJ} / \mathrm{m}^{2}$ and annual sunshine hours reaches $2835 \mathrm{~h}$, therefore the area has the geographical advantage of passive solar housing development[1,2]. Zhongwei region belong to the cold area, its coldest month average temperature is about $-5.5{ }^{\circ} \mathrm{C}$, the lowest temperature of $-10.7{ }^{\circ} \mathrm{C}[3]$. The construction of rural architecture in the region are mainly two forms of earth house and brick masonry house. Parts of the new brick masonry houses mostly adopt the simple passive solar collector technology, such as increasing the south window area, but the passive thermal effect of these buildings is not ideal.

In this paper, the indoor thermal environment of a passive solar brick masonry building located in Zhongwei region is tested, and the indoor thermal environment is analyzed. Through the research of this paper, it is expected to provide reference for improving the design of passive rural residential houses in this area.

\section{Test building}

The test building is a brick masonry building (as shown in Fig.1), which is located in Heilin village in Zhongwei region. The building is lying north to south with its length of east-west $21.3 \mathrm{~m}$ its width of north-south $5.4 \mathrm{~m}$. The bay of utility room is $4.2 \mathrm{~m}$ and there is a single window (2.0 $\mathrm{m} \times 1.8 \mathrm{~m}$ ) of aluminum alloy in south outside wall. The bay of main room and warehouse are $8.1 \mathrm{~m}$ and there are two windows $(2.2 \mathrm{~m} \times 1.8 \mathrm{~m})$ of aluminum alloy in south outside wall, respectively. 


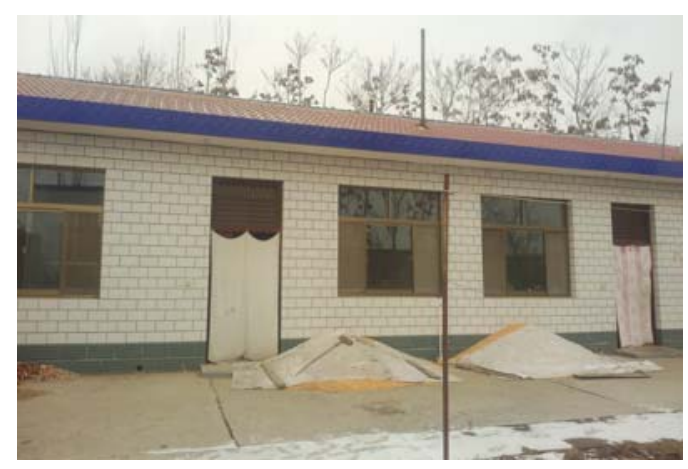

Fig.1 The south elevation of measured building

During the testing period, stoves and KANG were used only in the main rooms and there is no heating equipment in other unoccupied rooms. The area ratio of window to wall for utility room, main room and warehouse are $0.26,0.33,0.26$, respectively. All the doors are single aluminum doors. The thickness of the external walls is $370 \mathrm{~mm}$ and the thermal transfer coefficient is about $1.47 \sim 2.0 \mathrm{~W} / \mathrm{m}^{\circ}{ }^{\circ} \mathrm{C}$. Double-slope roof structure has been used in the building.

\section{Testing scheme}

The air temperature, relative humidity $(\mathrm{RH})$, surface temperature and solar radiation intensity were recorded from January 18th at ten a.m. for 24 hours. The air temperature and humidity was measured by a $175-\mathrm{H} 1$ precision hygrometer of self-recording with measuring accuracy $0.2^{\circ} \mathrm{C}$. The wall surface temperature was measured by a JTNT-C type heat transfer coefficient detector .The measuring points of indoor temperature were arranged as shown in Fig 2. The measuring point of outdoor temperature were placed in the shade. The values of total solar radiation and scattered solar radiation were measured using Domestic JTDL-4 type solar radiation meter.

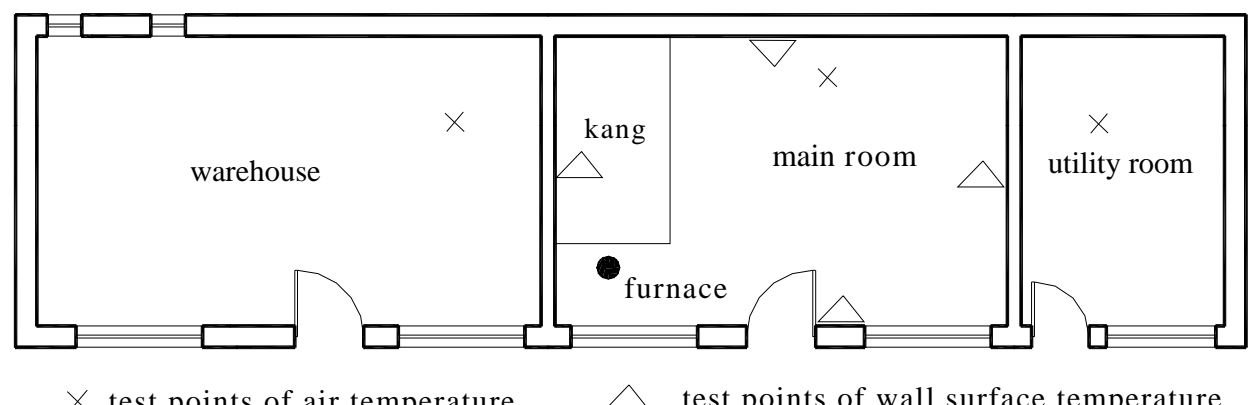

Fig.2 House plan and indoor measurement point distribution

\section{Results and discussion}

\subsection{Outdoors weather parameters}

The variation trend of outdoor air temperature is shown in Fig. 3. The intensity values of total solar radiation and scattered solar radiation are shown in Fig. 4.

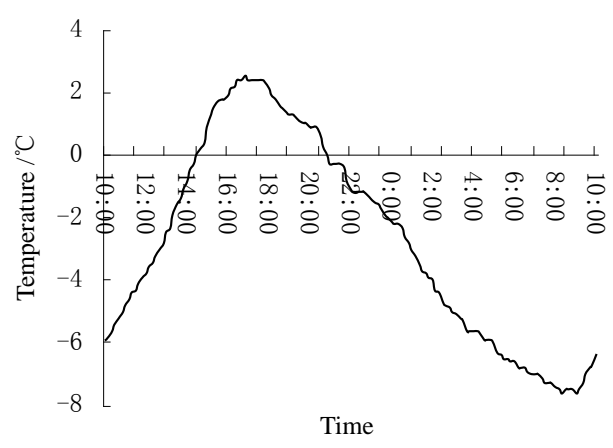

Fig.3 Outdoor temperature in measure day

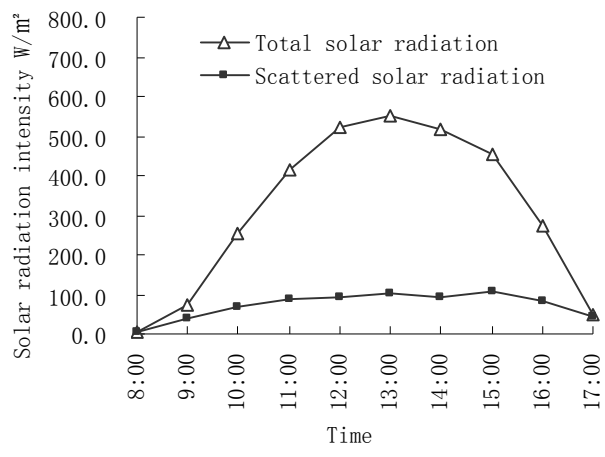

Fig.4 Solar radiation intensity

As shown in Fig. 3, the average value of outdoor air temperature in testing period was $-2.74^{\circ} \mathrm{C}$ 
which was close to the local average value of heating period[4]. The lowest value of the outdoor air temperature was $-7.6^{\circ} \mathrm{C}$ at $8: 30 \mathrm{a} . \mathrm{m}$. and the highest value was $2.5^{\circ} \mathrm{C}$ at $17: 00$ o'clock. The fluctuation range of out air temperature was about $10^{\circ} \mathrm{C}$.

From Fig. 4 it can be seen that the daylight hours was $10 \sim 11 \mathrm{~h}$ and the average value of total solar radiation was $286 \mathrm{~W} / \mathrm{m}^{2}$. The total solar radiation and scattered solar radiation reached the highest value at $13: 00$ o'clock which were $544.8 \mathrm{~W} / \mathrm{m}^{2}$ and $124.9 \mathrm{~W} / \mathrm{m}^{2}$, respectively. It is noteworthy that direct solar radiation accounted for $80 \%$ of total solar radiation. From the test results can be seen, the winter solar energy resources are very abundant in Zhongwei region and data of standard meteorological database also showed that the cumulative amount of solar radiation was about $5893 \mathrm{MJ} / \mathrm{m} 2$ in this area[5].

\subsection{Test and Analysis of Supermarket Thermal Environment}

The indoor air temperature and the wall surface temperature of diffident rooms are showed in Fig. 5 and Fig. 6
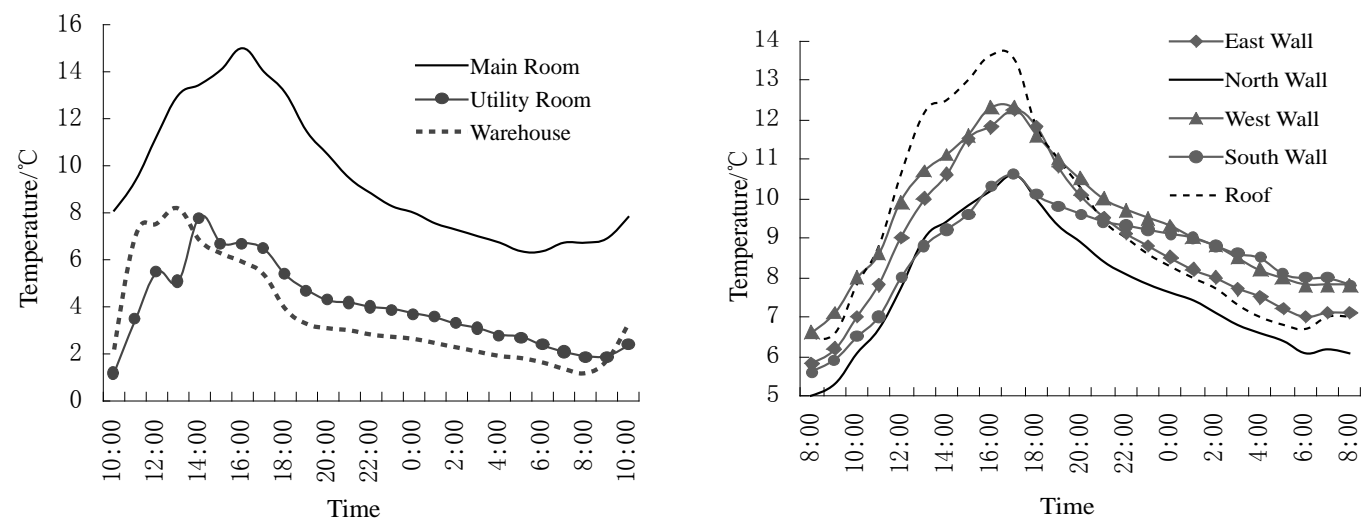

Fig.5 Hourly indoor air temperature Fig.6 Hourly internal surface temperature of main room

As shown in Fig. 5, the average value of air temperature in utility room and barn (the area ratio of window to wall is 0.26 , and there is no heating equipment.) were $3.98^{\circ} \mathrm{C}$ and $3.60^{\circ} \mathrm{C}$, respectively. The highest value of air temperature in utility room and barn was $7.8^{\circ} \mathrm{C}$ and $8.2^{\circ} \mathrm{C}$, respectively. In these rooms, in testing period, the lowest values of air temperature were nearly $1.0^{\circ} \mathrm{C}$ and the daily temperature difference was $6.8^{\circ} \mathrm{C}$. The average value, highest value and lowest value of indoor air temperature in main room (the main room with heating equipment ) were $9.5^{\circ} \mathrm{C}$, $15^{\circ} \mathrm{C}$ and $6.4^{\circ} \mathrm{C}$, respectively. The average and minimum values of indoor air temperatures in the main room was $6^{\circ} \mathrm{C}$ higher the other no heating equipment rooms. However, the temperature fluctuation of main room was $8.6^{\circ} \mathrm{C}$ which was amplitude close to the no heating equipment rooms.

As shown in Fig 6, in all the wall internal surface temperatures, the north wall internal surface temperature was the lowest value $7.7^{\circ} \mathrm{C}$ and the roof internal surface temperature was highest value $13.6^{\circ} \mathrm{C}$. For the other walls, the highest value was $11^{\circ} \mathrm{C}$. The internal surface temperature fluctuation value of roof was $7.1^{\circ} \mathrm{C}$ which was the maximum value and other wall surface temperature fluctuations were nearly $5.5^{\circ} \mathrm{C}$. From the analysis results can be found that the fluctuation of indoor air temperature and internal surface temperature were so large for the passive solar energy building which used direct solar window.

\section{Assessment of indoor thermal comfort}

At present, the following indoor thermal comfort evaluation index are the main types: effective temperature (SET), the standard effective temperature (ET), operating temperature, PMV-PPD, etc. [5]. The calculation of PMV index is very complicated, and the standard of PMV index is inappropriate for rural areas in the northwest. For other evaluation indexes, such as effective temperature, which gives a comprehensive consideration of temperature, humidity, wind speed and other conditions. However, in this testing, indoor thermal comfort evaluation can be accomplished without consideration for indoor humidity and the velocity of air. Because only when the 
environmental temperature is higher than $18^{\circ} \mathrm{C}$, the relative humidity greater than $6 \%$, humidity would become an important factor for human thermal comfort[6]. But during this testing, the relative humidity of indoor air ranged from $23 \%$ to $54 \%$ (Table 1 ) which had little effect on the indoor thermal comfort. Furthermore, the effect of humidity and wind velocity on thermal comfort could be neglected because the average value of indoor air velocity was less than $0.1 \mathrm{~m} / \mathrm{s}$. It has been proved that air temperature and radiation temperature are the most important factors in the influence of human thermal comfort [7]. Combine the local actual conditions and the results of the analysis, the northwest rural residences suitable for the operating temperature as the indoor thermal environment evaluation indexes, because the index considering the air temperature and the influence of radiant temperature on human thermal comfort. Operating temperature is the weighted average value of radiation temperature and air temperature, which can be calculated in terms of Eq.(1) as follows[8]:

$$
t_{0}=\frac{\bar{t}_{r} \alpha_{r}+t_{a} \alpha_{c}}{\alpha_{c}+\alpha_{r}}
$$

Where : $t_{0}$ - is operating temperature, ${ }^{\circ} \mathrm{C}$;

$t_{a}$ _ is indoor air temperature, ${ }^{\circ} \mathrm{C}$;

$\bar{t}_{r}$ — is radiant temperature (It's value is equal to the internal surface temperature), ${ }^{\circ} \mathrm{C}$;

$\alpha_{c}$ - is the coefficient of convective heat transfer, $\mathrm{W} /\left(\mathrm{m}^{2} \cdot{ }^{\circ} \mathrm{C}\right)$;

$\alpha_{r}$ - is the coefficient of radiate heat transfer, $\mathrm{W} /\left(\mathrm{m} 2 \cdot{ }^{\circ} \mathrm{C}\right)$;

In this paper, the radiation heat transfer coefficient and convection heat transfer coefficient is approximated equal [9] , so the Eq.(1) is:

$$
t_{0}=0.5 t_{a}+0.5 \bar{t}_{r}
$$

The average radiant temperature $\bar{t}_{r}$ can be calculated as Eq.(3) [10]:

$$
\bar{t}_{r}=\frac{t_{1} s_{1}+t_{2} s_{2}+\cdots+t_{n} s_{n}}{s_{1}+s_{2}+\cdots+s_{n}}
$$

Where: $t_{1}, t_{2}, t_{n}$ - is internal surface temperature of different walls and roof, ${ }^{\circ} \mathrm{C}$;

$s_{1}, s_{2}, s_{n}$ - is surface areas of different walls and roof, $\mathrm{m}^{2}$;

According to the testing results, by Eq. (3) calculates the hourly operating temperature of main room. The comparing the result of hourly operating temperature, hourly average radiation temperature and the hourly indoor air temperature, is shown in Fig. 7.

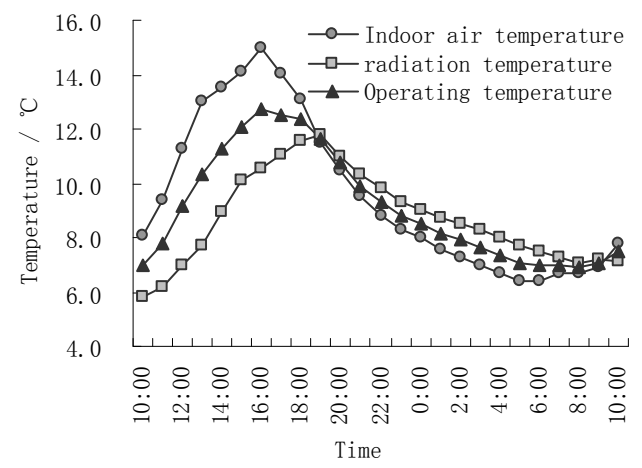

Fig.7 Daily variation of indoor air temperature, radiation and operating temperature

The average value of operating temperature and the fluctuation range are between air temperature and mean radiant temperature. The average value of operating temperature is $9.1^{\circ} \mathrm{C}$ and the fluctuation range is $6^{\circ} \mathrm{C}$. It can be seen from the results of the analysis of operation temperature that the local rural building indoor thermal environment is not ideal. Operating temperature depends 
on the indoor air temperature and radiation temperature. It is needed to strengthen the thermal insulation design to improve the indoor thermal environment quality.

\section{Improvement Measures of Indoor Thermal Environment}

The results obtained from the above analysis showed that during winter the indoor temperature is relatively low in testing building, which makes it difficult to meet the requirements of indoor thermal comfort. The thermal insulation design for improving the indoor thermal environment quality should be strengthen.

(1) Proper increasing the area of south windows

There is a little difference between the passive solar house of a direct gain solar window and the ordinary house in structure which is simple, low cost, easy to manufacture, install and maintenance. The south windows are main way to gain solar energy for the passive solar house, so the area of south windows are very significant for improving the indoor thermal environment. In the test building, the area of south windows to wall is nearly 0.3 which is lower than specification regulated data of $0.5[12]$. The larger area ratio of south window to wall the more solar energy can be collected, but too large area ratio of south window to wall can cause indoor overheat in summer.

(2) Increasing thermal mass

Thermal mass can improve the ability of building to reduce the indoor air temperature fluctuation, therefore increasing thermal mass is very important for passive solar building to improve indoor thermal comfort. The use of heavy masonry materials, Trombe walls or PCM can effectively restrain the indoor temperature fluctuation.

(3) Increasing the thermal insulation of walls and roof

In order to reduce the heat loss and improve the thermal environment quality, its necessary to increasing the thermal insulation of walls and roof. Adopting grass brick[13] or hollow brick as wall materials can effectively increase the wall heat transfer resistance and using EPS composite roof can significantly improve the insulation performance of roof.

\section{Conclusions}

(1) In testing period, the average intensity of total solar radiation was $286 \mathrm{~W} / \mathrm{m}^{2}$ and maximum value was $544.8 \mathrm{~W} / \mathrm{m}^{2}$. The solar energy is abundant in Zhongwei region where the sunshine time can reach more than 10 hours in winter, therefore it has great potentialities in developing passive solar house.

(2) The indoor thermal environment of passive solar building is influenced by the combined effect of indoor air temperature and radiant temperature, so it is suitable to evaluate the indoor thermal comfort by operating temperature.

(3) In Zhongwei rural area, due to lacking of relevant technology and effective scientific guidance, the indoor thermal environment was unsatisfactory. The thermal insulation design for improving the indoor thermal environment quality should be strengthen.

\section{Acknowledgements}

This work was supported by the National Natural Science Foundation of China (51278419); Key Social Development Program of Shaanxi Province (2012K12-04-01); Scientific Research Program Funded by Shaanxi Provincial Education Department (2013JK0945).

\section{References}

[1] Yin Zhiqiang. Development of solar thermal systems in China. Solar Energy Materials \& Solar Cells. Vol. 86(2005), 427

[2] Ruilcai Zhao, Li Zhao, Shuai Deng, Nan Zheng: Renewable and Sustainable Energy Reviews. 
Vol. 52(2015), p. 852

[3] GB50176-93.Thermal design code for civil building[s]. Beijing: China Planning Press,(1993).(in Chinese)

[4] JGJ26-2010. Design standard for energy efficiency of residential buildings in sever cold and cold zones[S]. Beijing:China Architecture \& Building Press,(2010). (in Chinese)

[5] Liu Jiaping. Architectural Physics [M]. Beijing: China Architecture and Building Press.(2000). (in Chinese)

[6] Fanger P O. Thermal comfort: analysis and applications in environmental engineering[M]. New York: McGraw -Hill Inc,(1970).

[7] HAN Jie, ZHANG Guo-qiang, ZHANG Quan, et al.: Building and Environment. Vol.42 (2007), p. 4043

[8] Liu Nianxiong, Qin Youguo. Building Thermal Environment[M].Beijing: Tsinghua University Press, (2005). (in Chinese)

[9] ASHRAE. ANSI/ASHRAE Standard 55-2004, Thermal Environmental Conditions for Human Occupancy[S]. Atlanta:ASHRAE, (2004).

[10] Borong L, Gang T, Peng W, et al.: Energy and Buildings. Vol. 36 (2004), p. 73

[11] JGJ/T267-2012. Technical code for passive solar buildings [S].Beijing: China Architecture \& Building Press, (2012). (in Chinese)

[12] Peizheng Ma, Lin-Shu Wang, Nianhua Guo: Applied Energy. Vol. 746 (2015), p. 84

[13] Taha Ashour, Heilco Georg, Wei Wu: Energy and Buildings. Vol. 43(2011), p.1960 